\title{
SOCJALIZUJĄCA ROLA AKTYWNOŚCI SPORTOWEJ DZIECI I MŁODZIEŻY W ŚWIETLE WSPÓŁCZESNEJ LITERATURY SOCJOLOGICZNEJ I HUMANISTYCZNEJ
}

\section{THE SOCIALIZING ROLE OF SPORTS ACTIVITIES OF CHILDREN AND YOUTH IN THE LIGHT OF CONTEMPORARY SOCIOLOGICAL AND HUMANISTIC LITERATURE}

\author{
Ryszard Polak $^{1(\mathrm{~A}, \mathrm{~B}, \mathrm{C}, \mathrm{D}, \mathrm{E}, \mathrm{F}, \mathrm{G})}$, Paweł Tarkowski ${ }^{1 \mathrm{~A}, \mathrm{~B}, \mathrm{C}, \mathrm{D}, \mathrm{E}, \mathrm{F}, \mathrm{G})}$ \\ ${ }^{1}$ Akademia Wychowania Fizycznego Józefa Piłsudskiego w Warszawie. Filia w Białej Podlaskiej, Polska \\ ${ }^{1}$ The Jozef Pilsudski University of Physical Education in Warsaw, Poland
}

Polak, R., Tarkowski, P. (2020). Socjalizująca rola aktywności sportowej dzieci i młodzieży w świetle współczesnej literatury socjologicznej i humanistycznej/ The socializing role of sports activities of children and youth in the light of contemporary sociological and humanistic literature, Rozprawy Społeczne/Social Dissertations, 14(3), 27-38. https://doi.org/10.29316/rs/125692

Wkład autorów/

Authors' contribution:

A. Zaplanowanie badań/ Study design

B. Zebranie danych/ Data collection

C. Dane - analiza i statystyki/ Data analysis

D. Interpretacja danych/ Data interpretation

E. Przygotowanie artykułu/ Preparation of manuscript

F. Wyszukiwanie i analiza literatury/

Literature analysis

G. Zebranie funduszy/

Funds collection

\section{Tabele/Tables: 0}

Ryciny/Figures: 0

Literatura/References: 41

Otrzymano/Submitted: 10.07.2020

Zaakceptowano/Accepted: 24.07.2020

\begin{abstract}
Streszczenie
W artykule podjęto analizę wybranych kilkudziesięciu dzieł współczesnych socjologów i teoretyków sportu i humanistów (publikacje książkowe i artykuły), którzy rozważali rolę sportu w socjalizacji dzieci i młodzieży we współczesnym świecie.

Materiał i metody. Wykorzystano współczesną literaturę źródłową i naukowe opracowania poświęcone głównie socjologii i filozofii oraz teorii sportu, oraz publikacje z zakresu pedagogiki sportu, w których badacze skupiali się na społecznej roli aktywności sportowej.

Wyniki. Autorzy wielu tekstów omawiających znaczenie sportu w życiu człowieka podkreślali również jego socjalizującą rolę, zwłaszcza w obecnych czasach, kiedy to postawy skrajnie indywidualistyczne niszczą więzi społeczne; istnieje w związku z tym konieczność większego zwrócenia uwagi osób dorosłych na wychowanie społeczne dzieci i młodzieży przez sport i aktywność ruchową.

Wnioski. W świetle przeprowadzonych badań sport dzieci i młodzieży ma bardzo duże znaczenie socjalizujące, a jego uprawianie jest konieczne nie tylko ze względów zdrowotnych, ale i społecznych.
\end{abstract}

Słowa kluczowe: socjalizacja, wychowanie, wartości moralne, fair play

\section{Summary}

The article analyzes a selection of selected papers publishes by contemporary sociologists, sports theorists and humanists (books and articles) who reflected on the role of sport in the socialization of children and adolescents in the contemporary world.

Material and methods. Contemporary reference sources and scientific studies devoted mainly to the sociology and philosophy as well as theory of sport were used. Publications in the field of sport pedagogy, in which researchers focused on the social role of sports activity.

Results. The authors of many texts discussing the significance of sport in human life have also emphasized its socializing role, especially nowadays, when extremely individualistic attitudes destroy social bonds. Therefore, it is necessary to pay more attention of adults to the social education of children and youth through sport and physical activity.

Conclusions. In the light of the research carried out, sports activities of children and adolescents show a great socializing significance, and practicing sport is necessary not only for health, but also for social reasons.

Key words: socialization, education, moral values, fair play

\footnotetext{
Adres korespondencyjny: Ryszard Polak, Zakład Nauk Humanistyczno-Społecznych, Akademia Wychowania Fizycznego Józefa Piłsudskiego w Warszawie Filia w Białej Podlaskiej, ul Akademicka 2, 21-500, Biała Podlaska, Polska; e-mail: ryszardpolak-ap@o2.pl, http://orcid.org/0000-0002-5617-2333 Copyright by: Państwowa Szkoła Wyższa im. Papieża Jana Pawła II w Białej Podlaskiej, Ryszard Polak 


\section{Uwagi wstępne o socjalizacji dzieci i młodzieży}

Podstawą stawania się człowieka istotą społeczną jest jego wchodzenie w interakcje $\mathrm{z}$ innymi ludźmi, dzięki którym ludzkie osoby przyswajają sobie podstawowe zasady funkcjonowania w społeczeństwie, w którym żyją. Proces ten nazywany jest socjalizacją, czyli uspołecznieniem. Człowiek rodzi się w określonym społeczeństwie, ale dopiero w trakcie swojego życia nabywa praktycznych zdolności do uspołecznienia się, dzięki czemu w kontaktach $\mathrm{z}$ innymi ludźmi następuje proces internalizacji postaw, wzorów, norm i wartości obowiązujących w danej grupie (Berger, Luckmann, 2010). Jest to proces międzypokoleniowej transmisji zachowań i przekonań funkcjonujących $\mathrm{w}$ danym społeczeństwie (Schaffer, 2006). Zdaniem socjologa Jana Szczepańskiego „socjalizacja modeluje sposoby zaspokajania popędów biologicznych, ale samych nie usuwa. Daje ona osobnikowi nawyki, umiejętności zachowania się w różnych sytuacjach społecznych i naturalnych, jakie spotyka on w społeczeństwie, i daje możliwość przystosowania się" (Szczepański, 1970, s. 32). Człowiek przygotowuje do pełnienia różnych ról, społeczeństwo zaś wskazuje mu drogę, jak należy postępować, aby osiągnął on zamierzone przez siebie cele życiowe. Pomaga ono mu stawać uczestnikiem życia w różnych jego wymiarach.

Proces socjalizacji nie przebiega w sposób linearny. W klasycznym ujęciu wskazuje się na dwie jego fazy: pierwotną i wtórną. Pierwsza z nich zaczyna się w początkowych miesiącach po urodzeniu i trwa do momentu, kiedy oprócz wspólnot należących do najbliższego otoczenia (rodzina, opiekunowie) wpływ na uspołecznienie dziecka zaczynaja mieć grupy zewnętrzne. Socjalizacja wtórna zaś ma swój początek $w$ wieku młodzieńczym człowieka i towarzyszy mu do śmierci. Ciężar wprowadzania do życia w społeczeństwie spoczywający na rodzicach jest wtedy stopniowo przejmowany przez instytucje, m.in. szkołę, środowisko rówieśnicze, media, organizacje społeczne. Inny podział etapów socjalizacji, niż preferowany przez socjologów, został zaproponowany przez przedstawicieli psychologii rozwojowej, którzy wykorzystując częściowo ustalenia socjologów, wyróżnili jej sześć faz: niemowlęctwo (do 1 roku życia), wczesne dzieciństwo (2-4 r.ż. - przedszkole), dzieciństwo (5-12 - szkoła), młodość (13-? - dojrzałość płciowa, koniec szkoły, kształcenie zawodowe), dorosłość (?-65 - praca, założenie własnej rodziny), starość (65-? - emerytura) (Tillmann, 2013).

Uczeni zgodni są co do tego, że uspołecznienie człowieka trwa ciągle, ale nie ulega wątpliwości, że najintensywniej przebiega on w najwcześniejszych latach jego życia. W okresie dzieciństwa i dorastania kształtowane są różne złożone zachowania społeczne dziecka, które w przyszłości zostaja wykorzystane do odgrywania przezeń różnych ról (Pieter, 1976; Wołoszyn, 1964). Już J. Locke wskazywał, iż człowiek przychodząc na świat jest jak

\section{Introductory remarks on the socialization of children and adolescents}

The basis for human becoming a social being is their interaction with other people, thanks to which human persons acquire the basic principles of functioning in the society in which they live. This process is called socialization. A person is born in a specific society, but only in the course of their life do they acquire practical skills to socialize, thanks to which in contacts with other people the process of internalization of attitudes, patterns, norms and values in a given group takes place (Berger, Luckmann, 2010). It is a process of intergenerational transmission of behaviors and beliefs functioning in each society (Schaffer, 2006). According to the sociologist Jan Szczepański, "socialization models the ways of satisfying biological drives, but does not remove them. It provides the individual with habits, the ability to behave in various social and natural situations that they encounter in society, and give the opportunity to adapt" (Szczepański, 1970, p. 32). People prepare themselves to fulfill various roles, while society shows them the way to act in order to achieve life goals. It helps them participate in life in its various dimensions.

The process of socialization is not linear. In classical terms, two phases are indicated: primary and secondary. The first one begins in the first months after birth and lasts until the moment when, apart from the communities belonging to the immediate environment (family, caregivers), external groups begin to influence the child's socialization. Secondary socialization begins in adolescence and accompanies them until his death. The burden of introducing into society, borne by the parents, is then gradually taken over by institutions, e.g. school, peer community, media, social organizations. A different division of the stages of socialization than that preferred by sociologists was proposed by representatives of developmental psychology who, partly using the findings of sociologists, distinguished six phases: infancy (up to 1 year of age), early childhood (2-4 years - kindergarten), childhood (5-12 - school), youth (13-? - sexual maturity, end of school, vocational training), adulthood (?-65 - work, starting own family), old age (65-? - retirement) (Tillmann, 2013).

Scientists agree that human socialization continues, but there is no doubt that it is most intensive in the earliest years of his life. During childhood and adolescence, various complex social behaviors of the child are shaped, and in the future, they are used to play various roles (Pieter, 1976; Wołoszyn, 1964). Already J. Locke indicated that a man coming into the world is like a tabula rasa, written down by successive experiences that affect further functioning. The process of learning about the world also concerns the phenomena of social life that people experience from the first days 
tabula rasa, która jest zapisywana przez kolejne doświadczenia mające wpływ na dalsze jego funkcjonowanie. Proces poznawania świata dotyczy również zjawisk życia społecznego, których doświadczają ludzie już od pierwszych dni i miesięcy po ich urodzeniu się. Zwracali na to uwagę zwłaszcza socjolodzy francuscy. Wg. E. Durkheima socjalizacja to „[...]wpływy wywierane przez generację dorosłych na tych, którzy nie są jeszcze gotowi do życia społecznego. Jej przedmiotem jest pobudzanie i rozwinięcie w dziecku określonej liczby stanów fizycznych, intelektualnych i moralnych wymaganych od niego zarówno przez społeczeństwo polityczne, zorganizowane jako całość, jak i przez konkretne środowisko, z którym jest ono konkretnie związane" (Filipiak, 2000, s. 94). We wczesnym okresie socjalizacji nadrzędnym jej zadaniem jest wyposażenie młodego człowieka w wiedzę, umiejętności i kompetencje, które są niezbędne do funkcjonowania w podstawowej grupie społecznej, jaką jest rodzina oraz poza nią (Szymański, 2013). Wielu badaczy wskazuje na fakt, iż socjalizacja młodego człowieka różni się od tej, której podana jest osoba dorosła. Uspołecznienie w okresie dzieciństwa dotyczy przed wszystkim regulacji popędów biologicznych, wprowadzania w świat obowiązujących norm i wartości. Wychowanie i edukacja ma wtedy charakter bardziej ogólny i idealistyczny, a socjalizowany przyjmuje $\mathrm{w}$ tym procesie status ucznia. Natomiast w przypadku osoby dorosłej przebieg socjalizacji w dużym stopniu zależy od pełnionych przez człowieka ról, a przyswajane przezeń zasady i normy postepowania sa $\mathrm{z}$ nimi wtedy ściśle związane. Tym samym jest on bardziej realistyczny (Mortimer, Simmons, 1978).

\section{Sport w świetle określeń współczesnych socjo- logów i humanistów}

Zinstytucjonalizowaną aktywnością mającą wpływ na socjalizację młodego człowieka jest sport. Pojęciem „sport” w języku potocznym posługujemy się bardzo często w sposób swobodny. Najczęściej kojarzy się ono z aktywnością fizyczną niekoniecznie związaną z obecnym w sporcie pierwiastkiem współzawodnictwa (Kowalczyk, 2002). Na gruncie nauk socjologicznych i humanistycznych powstało szereg definicji sportu. W większości z nich podkreśla się jednak komponent rywalizacji. Tak chociażby sport rozumie amerykański socjolog J. Coakley, dla którego jest on „zinstytucjonalizowaną aktywnością o charakterze rywalizacji, która wymaga fizycznego wysiłku lub określonych fizycznych zdolności i motywowana jest wewnętrznymi lub zewnętrznymi nagrodami" (Nosal, 2015, s. 20). Podobne ujęcie sportu zawarte jest w definicji zaproponowanej przez polskiego teoretyka kultury fizycznej M. Demela, który stwierdził, że sport to „działalność uprawiana systematycznie, według pewnych reguł, odznaczająca się silnym pierwiastkiem współzawodnictwa oraz tendencją do and months after their birth. This was especially pointed out by French sociologists. According to E. Durkheim's socialization is "[...] the influence exerted by the adult generation on those who are not yet ready for social life. Its subject is to stimulate and develop in a child a certain number of physical, intellectual and moral states required of them both by the political society, organized as a whole, and by the specific environment with which it is specifically associated" (Filipiak, 2000, p. 94) . In the early period of socialization, its main task is to equip a young person with knowledge, skills and competences that are necessary to function in the basic social group, being the family and beyond (Szymański, 2013). Many researchers point out that the socialization of a young person differs from that of an adult. Socialization during childhood mainly concerns the regulation of biological drives, introducing binding norms and values into the world. Upbringing and education are then of a more general and idealistic character, and the socialized takes on the status of a student in this process. On the other hand, in the case of an adult, the course of socialization largely depends on the roles performed by a person, and the principles and norms of conduct they acquire are then closely related to them. Thus, it is more realistic (Mortimer \& Simmons, 1978).

\section{Sport in the light of the terms of contemporary sociologists and humanists}

Sport is an institutionalized activity that has an impact on the socialization of a young person. We use the term "sport" in colloquial language very often quite freely. Most often it is associated with physical activity not necessarily related to the element of competition present in sport (Kowalczyk, 2002). Based on sociological and humanities, several definitions of sport have been developed. However, most of them emphasize the rivalry component. For example, sport is understood by the American sociologist J. Coakley as "an institutionalized competitive activity that requires physical effort or specific physical abilities and is motivated by internal or external rewards" (Nosal, 2015, p. 20). A similar approach to sport is included in the definition proposed by the Polish theoretician of physical culture M. Demel who stated that sport is "an activity carried out systematically, according to certain rules, characterized by a strong element of competition and a tendency to achieve better and better results, aimed at manifesting physical fitness"(Kunicki, 2011, p. 60). According to W. 
osiągania coraz lepszych wyników, mająca na celu manifestację sprawności ruchowej" (Kunicki, 2011, s. 60). Według W. Lipońskiego z kolei o sporcie możemy mówić w przypadku świadomej działalności człowieka, w której zawarte są: „indywidualna lub zespołowa rywalizacja w pokonywaniu czasu, przestrzeni, przeszkód naturalnych lub sztucznych oraz przeciwnika; doskonalenie cech sprawności fizycznej i sił psychicznych (woli, charakteru, zasad moralnych); dobrowolność uczestnictwa; podporządkowanie się przepisom i regułom gry, w tym także dyrektywom fair play; brak bezpośrednich celów pozasportowych (militarnych czy produkcyjnych)" (Ziółkowski, 2004, s. 18). Mike McNamee zaś wskazuje na cztery elementy warunkujące, to, że daną aktywność nazy wa się sportem: umowne cele; zbiór zasad, które jasno wskazują w jakich warunkach cel jest uzyskiwany; zasady regulujące sposób realizacji celów; postawa uczestników nastawiona na realizację umownego celu (Nosal, 2015). W przypadku dzieci i młodzieży trudno mówić o uprawianiu przez nich sportu na poziomie profesjonalnym (zawodowym), bardziej natomiast o aktywności sportowej i uczestnictwie w sporcie, które przejawia się w regularnych ćwiczeniach fizycznych oraz zorganizowanych treningach i zawodach w szkole, klubach sportowych oraz indywidualnych ćwiczeniach.

\section{Najistotniejsze funkcje sportu w świetle współ- czesnej literatury przedmiotu}

Sport pełni szereg funkcji; do tych najważniejszych z nich należą: zdrowotna, wolicjonalna, rozrywkowa, propagandowa, integracyjna, wychowawcza, socjalizacyjna. Niewątpliwie uczestnictwo w sporcie może odgrywać istotną rolę w uspołecznieniu człowieka. Według K. Heinemanna jest to związane z trzema jego cechami. Pierwszą z nich jest: „... istnienie silnego pierwiastka normatywnego, który sprawia, iż role społeczne w sporcie są czytelne i bardzo precyzyjnie określone, a wszelkie odstepstwa od nich natychmiast sankcjonowane" (Sas - Nowosielski, 2002, s. 104). Kolejną grupą cech jest: wytrwałość, systematyczność, nie uleganie przez człowieka porażkom. Uczestnictwo w sporcie to także często bycie członkiem klubu sportowego, a tym samym aktywność w nowej sferze uczestnictwa społecznego, w strukturze, gdzie funkcjonuja nowe formy relacji społecznych, niedoświadczanych wcześniej przez młodego człowieka w rodzinie czy szkole. Socjalizacja poprzez sport to także łączenie tego działania, które jest dla człowieka przyjemne, z czynnościami mającymi społecznie pożyteczny charakter. Dla wielu młodych ludzi sport jest przede wszystkim wartością autoteliczną, ale też może być instrumentalną, wówczas wartości zewnętrzne (etos pracy, poszanowanie przepisów, zasad) biorą górę nad wewnętrznymi (zabawą, przyjemnością, wyzwaniem) (Ommundsen, Løndal, Loland, 2014). Ważną rolę aktywności fizycznej w uspołecznia-
Lipoński, we can talk about sport in the case of conscious human activity, which includes: "individual or team competition in overcoming time, space, natural or artificial obstacles and the opponent; improving the features of physical fitness and mental strength (will, character, moral principles); voluntary participation; compliance with the rules and regulations of the game, including fair play directives; no direct non-sport goals (military or production)" (Ziółkowski, 2004, p. 18). Mike McNamee, on the other hand, points to four determinants that an activity is called a sport: conventional goals; a set of rules that clearly indicate under what conditions the goal is achieved; rules governing the manner of achieving goals; attitudes of participants focused on achieving the contractual goal (Nosal, 2015). In the case of children and adolescents, it is difficult to talk about practicing sport professionally (as vocational), but more about sports activity and participation in sports, which is manifested in regular physical exercises as well as organized training and competitions at school, sports clubs and individual exercises.

The most important functions of sport in the

Sport has several functions; the most important of them include health, volitional, entertainment, propaganda, integration, educational, socialization functions. Undoubtedly, participation in sport can play an important role in human socialization. According to $\mathrm{K}$. Heinemann, it is related to three of his features. The first one is: "... the existence of a strong normative element which makes social roles in sport clear and very precisely defined, and any deviations from them are immediately sanctioned" (Sas-Nowosielski, 2002, p. 104). Another group of features includes perseverance, regularity, and not succumbing to failures. Participation in sport often means being a member of a sports club, and thus an activity in a new sphere of social participation, in a structure where new forms of social relations function, previously inexperienced by a young person in a family or school. Socialization through sport also means combining this activity that is pleasant for people with activities of a socially beneficial nature. For many young people, sport is primarily an autotelic value, but it can also be instrumental, then external values (work ethos, respect for regulations, rules) take precedence over internal ones (fun, pleasure, challenge) (Ommundsen, Løndal, Loland, 2014). The important role of physical activity in socializing children and adolescents was also noticed by Polish theorists of physical education, M. Demel and A. 
niu dzieci i młodzieży dostrzegali również polscy teoretycy wychowania fizycznego M. Demel oraz A. Skład, którzy pisali, że: „Sytuacje wychowawcze, które występują we współzawodnictwie, kooperacji sportowej w czasie zawodów, turniejów, rajdów, lotów, wspinaczki, żeglugi, przeżycia zawodnika i kibica, zwycięzcy i pokonanego - to sytuacje niespotykane w innych działach wychowania. Bywa przecież, że dany osobnik jest niewrażliwy na rutynowe środki i metody wychowania moralnego, a jego sylwetka społeczno-moralna kształtuje się właśnie - i głównie - w procesie wychowania fizycznego, którego <<działanie uboczne>> okazuje się w tym wypadku decydujące" (Demel, Skład, 1986, s. 78).

\section{Sport a wspólnoty społeczne i moralność wspól- notowa}

Jednym z warunków przyczyniających się do zaistnienia społeczeństwa jest wytworzenie się poczucia wspólnoty u poszczególnych ludzi. W społeczeństwie ponowoczesnym, w którym osłabieniu ulega rola religii oraz autorytetów, sport staje się coraz ważniejszą płaszczyzną integracji. Uczestnictwo w sporcie kształtuje jedną z ważniejszych wartości społecznych, jaką jest solidarność, która na gruncie tej aktywności człowieka tworzy się przede wszystkim przez członkostwo w zespole. Jak pisze S. Kowalczyk, „Wspólnota zainteresowań, treningów, gry, celów życiowych, etosu, itp. wytwarza więź przyjaźni łączącą członków drużyny sportowej. Jest ona nie tylko wartością powstał na bazie wartości ludycznych (gry, rozrywki, radości ze wspólnego przebywania), ale najczęściej także wspólnotą egzystencjalno-aksjologiczną. Dobrem wspólnym ludzi uprawiających sport, amatorów i zawodowców, jest szeroko rozumiane dobro człowieka: zdrowie, odpoczynek, fizyczny i psychiczny rozwój, kreatywność. Drużyna sportowa jest źródłem trwałych przyjaźni, zapewnia człowiekowi obecność życzliwych ludzi, uczy lojalności, braterstwa, umiejętności społecznego współżycia, wyzwala inicjatywę i pomysłowość" (Kowalczyk, 2003, s. 27).

Socjalizacja jest procesem wprowadzania człowieka w świat obowiązujących go norm, a sport jest dziedziną, w której mamy do czynienia $\mathrm{z}$ nagromadzeniem różnego rodzaju zasad i przepisów, trwałych i ponadczasowych, które z kolei podnoszą moralny wymiar ludzkiego życia. Według Z Krawczyka w ramach czystej rywalizacji sportowej wśród dzieci i młodzieży, a także podczas poznawania i przestrzegania przepisów i reguł gry obowiązujących w jakiejś dyscyplinie, zawodnicy uczą się takich zasad życia społecznego, jak: „potrzeba pokoju, współpracy, tożsamości narodowej, wzajemnego zrozumienia oraz autonomii i wolności" (Ziółkowska, 2004, s. 20). Na internalizację jednostki z wykorzystaniem sportu wskazują też inni badacze, którzy wręcz piszą, że uspołecznienie poprzez
Skład who wrote that: "Educational situations that occur in competition, sports cooperation during competitions, tournaments, rallies, flights, climbing, sailing, the experiences of the competitor and the fan, the winner and the loser - the situations are unheard of in other areas of education. It happens, after all, that a given individual is insensitive to routine means and methods of moral education, and his socio-moral profile is shaped precisely - and mainly - in the process of physical education, the «side effect» of which turns out to be decisive in this case “(Demel , Composition, 1986, p. 78).

\section{Sport and social communities and community morality}

One of the conditions contributing to the existence of society is the creation of a sense of community in individual people. In a postmodern society where the role of religion and authorities is weakening, sport is becoming an increasingly important area of integration. Participation in sport shapes one of the most important social values, which is solidarity, which is created primarily by membership in a team based on this human activity. As S. Kowalczyk writes, "The community of interests, training, games, life goals, ethos, etc. creates a bond of friendship between members of a sports team. It is not only a value created on the basis of ludic values (games, entertainment, the joy of being together), but most often also an existentialaxiological community. The common good of people practicing sports, amateurs and professionals is the universally understood good of humans: health, rest, physical and mental development, creativity. A sports team is a source of lasting friendships, ensures the presence of kind people, teaches loyalty, brotherhood, social coexistence skills, triggers initiative and creativity" (Kowalczyk, 2003, p. 27).

Socialization is the process of introducing people into the world of the norms that apply to them, and sport is a field in which we deal with the accumulation of various types of rules and regulations, permanent and timeless, which in turn raise the moral dimension of human life. According to Z. Krawczyk, as part of pure sports rivalry among children and adolescents, as well as while learning and observing the rules and rules of the game in a given discipline, players learn such rules of social life as: "the need for peace, cooperation, national identity, mutual understanding and autonomy and freedom" (Ziółkowska, 2004, p. 20). The internalization of the individual with the use of sport is also indicated by other researchers who even write that socialization through sport is one of the guarantors of the stability and survival of society (Sage, 1979). It is through sports activities that the personality of children and 
sport jest jednym z gwarantów stabilności i przetrwania społeczeństwa (Sage, 1979). To poprzez aktywność sportową kształtuje się osobowość dzieci i młodzieży, utrwala się właściwe postawy i nawyki ważne w życiu osobistym i społecznym. Chociażby warto wspomnieć, że podczas udziału w rywalizacji sportowej wymaga się od ich uczestników poszanowania reguł gry. Postępowanie takie, jak pisał J. Kosiewicz „ma wydźwięk pragmatyczny, tak jak postępowanie zgodnie z zasadami kodeksu prawa administracyjnego, cywilnego czy karnego" (Kosiewicz, 2010, s. 34). Młody człowiek uczy się szacunku dla obowiązującego prawa. Poprzez udział w aktywności sportowej kształtuje się jego moralność, która ewoluuje od absolutnego do relatywnego przestrzegania norm, „od zewnętrznego do wewnętrznego umiejscowienia ich źródeł (od potępienia przez dorosłych i rówieśników do samopotępienia za ich nieprzestrzeganie" (Ziółkowski, 2004, s. 13).

\section{Zasada fair play w sporcie i jej społeczno - wy- chowawcze znaczenie}

Socjalizującej roli sportu pomaga obecna w nim reguła fair play, która swoje korzenie ma w kręgach rycerskich epoki starożytnej i średniowiecza. Pojęcie to zostało użyte po raz pierwszy przez Wiliama Szekspira w dramatach Życie i śmierć króla Jana oraz Burza" (Lipoński, 2014), a w sporcie przyjęło się zwłaszcza pod koniec XIX w. Jest to reguła etyczno-moralna zawodników uprawiających sport, według której od uczestników rywalizacji w tej dziedzinie oczekuje się przestrzegania obowiązujących w niej ustalonych wcześniej zasad, które wyrażają się $\mathrm{w}$ takich zachowaniach, jak: bezinteresowne poszanowanie reguł gry, szacunek dla przeciwnika, umożliwienie równych szans w rywalizacji, niewykorzystywanie przewagi losowej, rezygnacja z praktycznych korzyści ze zwycięstwa, minimalizacja cierpień przeciwnika. Na gruncie szkolnych zawodów dzieci i młodzież są zapoznawane z głównymi zasadami olimpizmu. Młodzi ludzie doświadczają faktu, że tzw. czysta gra to w praktyce respektowanie zasad opartych na tradycji, prawym sumieniu i powszechnie akceptowanej moralności. Fair play ma wymiar indywidualny i zbiorowy. Jak pisze J. Nowocień, „fair play obejmuje głównie stosunek sportowca do siebie samego, jako współzawodnika i wyraża się odpowiedzialnością za własne czyny. Kategoria ta zawiera: przestrzeganie przepisów gry oraz bezwzględne akceptowanie decyzji sędziego, relacje zawodnika z przeciwnikiem (zarówno w zakresie fizycznym, jak i psychicznym), samokontrolę w zakresie walki, zwycięstwa lub porażki" (Nowocień, 2001, s. 73).

Nauczyciel i wychowawcy oczekują, że młodzi sportowcy nie tylko będą postępować fair play $\mathrm{w}$ trakcie obecności na stadionie, ale obowiązujące zasady i reguły będa przenosić na inne obszary swojej aktywności. O ile z tą etyczno-moralną re- adolescents is shaped, and appropriate attitudes and habits significant in personal and social life are established. It is worth mentioning that when participating in sports competitions, participants are required to respect the rules of the game. Such actions, as J. Kosiewicz wrote, "have a pragmatic overtone, just like proceedings in accordance with the principles of the administrative, civil or criminal code" (Kosiewicz, 2010, p. 34). Young men learn to respect the applicable law. By participating in sports activities, their moralities are shaped, evolving from absolute to relative compliance with norms, "from the external to the internal location of their sources (from condemnation by adults and peers to self-condemnation for non-compliance with them" (Ziółkowski, 2004, p. 13).

\section{The principle of fair play in sport and its social and educational significance}

The socializing role of sport is supported by the fair play rule. It has roots in the knightly circles of the ancient and medieval epochs. This term was used for the first time by William Shakespeare in the dramas The Life and Death of King John and The Tempest (Lipoński, 2014), and in sport it became especially popular at the end of the 19th century. It is an ethical and moral rule of players practicing sports, according to which competition in this field, players are expected to comply with the previously established rules, as expressed in such behavior as: disinterested respect for the rules of the game, respect for the opponent, enabling equal opportunities in competition, not using random advantage, giving up the practical benefits of winning, minimizing the suffering of the adversary. During school competitions, children and youth are acquainted with the main principles of Olympism. Young people experience the fact that the socalled "fair play" means respecting rules based on tradition, right conscience and the generally accepted morality. Fair play has an individual and collective dimension. As J. Nowocień writes, "fair play mainly covers the athlete's attitude towards himself as a competitor and expresses responsibility for his own actions. This category includes: compliance with the rules of the game and absolute acceptance of the referee's decisions, relations between a player and an opponent (both physically and mentally), self-control in terms of fight, victory or defeat" (Nowocień, 2001, p. 73).

The teacher and tutors expect that not only will young athletes act fair play when present at the stadium, but they will also transfer the applicable rules and regulations to other areas of their activity. While young people have a chance to meet this ethical and moral rule also in non-sport areas of 
gułą młody człowiek ma szanse spotkać się z również w pozasportowych obszarach działalności, to jednak najefektywniej socjalizacja w tym zakresie jest przeprowadzana na gruncie sportu gdyż - jak podkreślają Zofia i Ryszard Żukowscy, „Postawy wobec fair play kształtuje się w toku życia człowieka i procesu jego wychowania w rodzinie, szkole, poza szkołą. Jeśli w tym, procesie rozwoju osobniczego i wychowania człowiek nie zetknie się z tymi wartościami i nikt postaw wobec tych wartości nie będzie kształtował - trudno oczekiwać ich u dorosłych osobników w społeczeństwie. Sport i olimpizm natomiast są same w sobie nośnikiem tych wartości, stąd dużo większa łatwość naturalnego kształtowania postaw wobec wartości fair play u uczestników aktywności sportowej" (Żukowska, Żukowski, 2010, s. 61).

Jedną z wartości często podkreślanych przez współczesnych badaczy zajmujących się humanistycznymi i społecznymi aspektami sportu jest szacunek dla drugiego człowieka (Holt, Tink, Mandigo, Fox, 2008; Khaled Ahmad Ibrahim, Brée, Naja, 2017). H. Zdebska wskazuje na sytuacje kiedy w zmaganiach sportowych kształtowana jest postawa szacunku: „Świadczą o tym gesty wynikające zarówno z oficjalnego ceremoniału zawodów (m.in. powitanie zespołów przed meczem i podziękowanie sobie za wspólną grę po jej zakończeniu, jak też $\mathrm{w}$ niepisanych regułach obowiązujących $\mathrm{w}$ trakcie walki sportowej, tak mocno akcentowanych w kodeksie etycznym fair play" (Zdebska, 2010, s. 57). Natomiast Jerzy Nowocień podkreśla, że sport budowany w oparciu o system wartości olimpijskich, jest jednym $z$ najlepszych narzędzi do kształtowania demokracji i społeczeństwa obywatelskiego, ponieważ „olimpizm daje się traktować jako demokratyczny i międzykulturowy system wychowania poprzez sport" (Nowocień, 2014, s. 202). Z racji powszechnego dostępu do sportu rozumianego jako aktywność ruchowa, każda osoba w nim uczestnicząca korzysta z podstawowych praw obywatelskich: do zdrowia, integralności, dobrego samopoczucia psycho-fizycznego (Stryczek, 2011).

\section{Sport a wartości moralne}

Wśród dyscyplin sportowych są takie, w których, oprócz pierwiastka rywalizacji istotną rolę odgrywa ich wymiar aksjologiczny, a może nawet staje się on ważniejszy w wychowaniu społecznym człowieka. Najczęściej jako przykład takich dyscyplin, w których wartości moralne mają duże znaczenie, podaje się wschodnie sztuki walki, nazywane też często „sztukami życia”. Uczestnictwo w nich to nabywanie wielu społecznie pożądanych wartości, do których Wojciech Cynarski zalicza: „osobowe (model mistrza sztuk walki), etyczne (szacunek, honor, odwaga, dyscyplina), estetyczne, zdrowotne, utylitarne, symboliczne, patriotyczne i uniwersalne" (Cynarski, 2012, s. 98). Ponadto osoby trenujące te dyscypliny kształtują w sobie samodyscyplinę, activity, the most effective socialization in this area is carried out in the field of sport because as emphasized by Zofia and Ryszard Żukowski, "Attitudes towards fair play are shaped in the course of a person's life and the process of their upbringing in the family, school, outside school. If in this process of personal development and upbringing a person does not encounter the values, and no one shapes attitudes towards the values it is difficult to expect them in adult individuals in society. On the other hand, sport and Olympism are in themselves carriers of the values, hence a much greater ease of natural shaping attitudes towards fair play among participants of sports activity" (Żukowska, Żukowski, 2010, p. 61).

Respect for another human being is one of the values often emphasized by contemporary researchers dealing with the humanistic and social aspects of sport (Holt, Tink, Mandigo, Fox, 2008; Khaled Ahmad Ibrahim, Brée, Naja, 2017). H. Zdebska points to situations where an attitude of respect is formed in sports struggles: "This is evidenced by gestures resulting both from the official ceremony of the competition (including greeting the teams before the match and thanking each other for playing together after it, as well as in unwritten rules in force during sports combat, so strongly emphasized in the code of ethics of fair play" (Zdebska, 2010, p. 57). On the other hand, Jerzy Nowocien emphasizes that sport built on the basis of the Olympic values system is one of the best tools for shaping democracy and civil society, because "Olympism can be treated as a democratic and intercultural system of education through sport" (Nowocień, 2014, p. 202). Due to universal access to sport, understood as physical activity, each participant enjoys the basic civil rights: to health, integrity, psycho-physical well-being (Stryczek, 2011).

\section{Sport and moral values}

Among sports disciplines, there are those in which, apart from the element of competition, their axiological dimension plays an important role, and it may even become more important in human social education. Eastern martial arts are most often mentioned as an example of such disciplines in which moral values are of great importance. They are also often called "arts of life". Participation in them means acquiring many socially desirable values, among which Wojciech Cynarski includes: "personal (model of a martial arts master), ethical (respect, honor, courage, discipline), aesthetic, health, utilitarian, symbolic, patriotic and universal ones" (Cynarski , 2012, p. 98). Moreover, people who practice such disciplines develop self-discipline, 
wytrwałość, samokontrolę, pokorę, życzliwość oraz tolerancję dla innych kultur (Cynarski, Lee-Barron, 2014). We wschodnich sztukach walki ważną rolę odgrywa trener/instruktor (sensei), który nie tylko jest nauczycielem ruchu i tradycji, ale również stanowi dla młodych zawodników wzorzec o wysokim poziomie moralnym $\mathrm{w}$ procesie internalizacji (Pietrzak, Cynarski, 2000).

\section{Uspołecznienie dzieci i młodzieży przez sport w szkole}

Socjalizacja jest nie tylko procesem przygotowującym młodych ludzi do pełnienia przez nich ról społecznych, ale także przyczynia się do większego uspołecznienia człowieka. Wielu naukowców zwraca uwagę na fakt, że sport odgrywa ważną rolę w socjalizacji chłopców do wykonywania przez nich tradycyjnych ról płciowych. U. Kulczycka pisze, że „Sport określa zachowania agresywne, siłę oraz twardość jako normę męskości - i w nią socjalizuje. Konstruuje tożsamość młodych mężczyzn i reprodukuje męską hegemonię, albowiem bohater sportowy jest postrzegany jako prawdziwy mężczyzna" (Kulczycka, 2019, s. 89). Inaczej jest w przypadku dziewcząt, które poprzez aktywność sportową socjalizują się do nietradycyjnych ról, tym samym łamią pewne społeczne stereotypy dotyczące płci, które zaczynające się rozwijać u dziecka na przełomie pierwszej i drugiej dekady jego życia. Ponadto, jak zauważa N. Organista, „W przeciwieństwie do chłopców, dziewczęta nie zdobywają uwagi rówieśników i szacunku w społeczności szkolnej dzięki sukcesom sportowym, ale dzięki atrakcyjnemu wyglądowi" (Organista, 2012, s. 197). Są one w mniejszym stopniu zainteresowane uczestnictwem w aktywności sportowej, a jeżeli już, to podejmują się uprawiania mniej angażujących ćwiczeń. Pogłębianiu stereotypowego postrzegania płci niewątpliwie sprzyja tradycyjny podział rywalizacji sportowej wg kategorii płci oraz na sporty „typowo” męskie i kobiece. Oczywiście ignorowanie różnic fizjologicznych i ich wpływu na wyniki sportowe kobiet i mężczyzn nie jest uzasadnione. Jednak, tak jak sport rodzi stereotypy kobiety, może również je łagodzić, przeciwdziałać reprodukcji społecznego podziału ról płciowych. Przykładem mogą być dyscypliny uprawiane koedukacyjnie, w których wspólnie - w jednej drużynie - rywalizują ze sobą dziewczęta i chłopcy, np. korfball. W tym przypad$\mathrm{ku}$ najbardziej charakterystyczne cechy dla sportów męskich i kobiecych, takie jak siła fizyczna, prawdopodobieństwo kontaktu fizycznego, estetyka stają się mniej znaczące, liczy się natomiast przede wszystkim poczucie wspólnoty, współpraca i zespołowe osiąganie celu.

Jak zauważa J. Lipiec, „Wejście w świat sportu, to przyjęcie do wiadomości koniecznego, konstytutywnego faktu spotkania innych, a więc bezpośredniego wejścia w grupę i współtworzenia w jej ramach wedle intencjonalnej wspólnoty oby- perseverance, self-control, humility, kindness and tolerance for other cultures (Cynarski, Lee-Barron, 2014). In eastern martial arts, an important role is played by the trainer/instructor (sensei) who is not only a teacher of movement and tradition, but also serves as a model of high moral standards for young players in the process of internalization (Pietrzak, Cynarski, 2000).

\section{Socializing children and adolescents through sport at school}

Socialization is not only a process that prepares young people for their social roles, but also contributes to a greater socialization of a person. Many researchers point out that sport plays an important role in socializing boys to perform traditional gender roles. U. Kulczycka writes that "sport defines aggressive behavior, strength and hardness as the norm of masculinity - and socializes in it. It constructs the identity of young men and reproduces male hegemony, because a sports hero is perceived as a real man" (Kulczycka, 2019, p. 89). The situation is different in the case of girls who, through sports activities, socialize into nontraditional roles, thus breaking certain social stereotypes regarding gender that begin to develop in a child at the turn of the first and second decades of his life. What is more, as N. Organista notes, "unlike boys, girls do not gain peers' attention and respect in the school community thanks to their sports successes, but thanks to their attractive appearance" (Organista, 2012, p. 197). They are less interested in participating in sports activities, and if they are, they undertake less engaging exercises. The traditional division of sports competitions into gender categories and into "typically" male and female sports undoubtedly contributes to the deepening of the stereotypical perception of gender. Of course, ignoring the physiological differences and their impact on the sports performance of men and women is not justified. However, just as sport breeds stereotypes of women, it can also alleviate them and counteract the reproduction of the social division of gender roles. Disciplines practiced co-educational in which girls and boys compete together - in one team, e.g. korfball can be an example. In this case, the most characteristic features for men's and women's sports, such as physical strength, the likelihood of physical contact, aesthetics, become less significant, but what matters most is the sense of community, cooperation and team achievement of the goal.

As J. Lipiec notices, "Entering the world of sport means accepting the necessary, constitutive fact of meeting others, and thus directly entering a group and co-creating it according to an intentional community of customs, norms and goals" (Lipiec, 2012 , p. 17). Participation in a sports group brings several positive benefits to a young person, as evidenced by, for example, the results of surveys 
czajów, norm, i celów" (Lipiec, 2012, s. 17). Udział grupie sportowej przynosi szereg pozytywnych korzyści młodemu człowiekowi, czego dowodem mogą być np. wyniki badań przeprowadzanych wśród uczniów klas sportowych, które wskazują, że uczęszczające do nich osoby charakteryzują się większą dyscypliną, wyższą oceną zachowania, poczuciem wspólnego interesu, a wyniki w nauce są lepsze lub równorzędne do wyników rówieśników (Nowocień, 2001). Trening sportowy według polskich luminarzy teorii sportu M. Demela i A. Skład wymaga od osoby jemu poddanej „poczucia odpowiedzialności, konsekwencji, samodyscypliny, podporzadkowania się regułom gry i arbitrażowi, a wszelkie naruszenia tych zasad mszczą się same przez się lub są sankcjonowane przez sędziów" (Sas-Nowosielski, 2002, s. 60). Często podkreślaną zaletą aktywności sportowej w procesie socjalizacji młodego pokolenia jest kształtowanie zdolności do współpracy w grupie, która jest cenionym elementem uczestnictwa w życiu społecznym, wyznacznikiem stopnia uspołecznienia. Przede wszystkim następuje ona w trakcie gier i zabaw zespołowych, które mają wiele wartościowych cech. Fakt ten został dostrzeżony od momentu, kiedy gry także zagościły w edukacji jako jeden ze sposobów naturalnego treningu dziecka (Zdebska, 2012). Wśród cech, które są nabywane przez dzieci i młodzież przez zespołowe uprawianie sportu M. Tomecka wymienia: kształtowanie umiejętności dzielenia się z innymi doświadczeniem oraz poczucie $\mathrm{z}$ nimi solidarności; wyzbycie się egoizmu, rezygnacja $\mathrm{z}$ indywidualnych korzyści dla dobra ogółu (Tomecka, 2012). Drużyna złożona z rówieśników dla młodych ludzi staje się ważną, jeśli nawet nie najważniejszą grupą, do której przynależą, w której nawiązują się więzi międzyosobowe o szczególnym charakterze.

\section{Higiena indywidualna a sport i socjalizacja dzie- ci i młodzieży}

W ramach uczestnictwa w sporcie realizowany jest również wzór higieniczny kultury fizycznej, którego celem jest dbałość o zdrowie oraz walka $\mathrm{z}$ chorobą, zgodnie z maksymą rzymskiego poety Juewenalisa: „W zdrowym ciele zdrowy duch”. W procesie uspołecznienia młodzi ludzie nabywają właściwego stosunku do zdrowia jako cennej wartości nie tyko z indywidualnego punktu widzenia, ale też ogółu społeczeństwa. Młodzi sportowcy będąc pod opieką nauczycieli oraz trenerów zachęcani są do zdrowego stylu życia: odżywiania się, nawodnienia, higieny osobistej (Khaled Ahmad Ibrahim, Brée, Naja, 2017). Wielu z nich udział w rywalizacji sportowej kończy wraz w wejściem w dorosłość, jednak wcześniej wypracowane wzory zachowań często są dalej przez nich powielane. Badania ukazują pewną istotną zależność pomiędzy byciem aktywnym fizycznie w okresie dzieciństwa i podobnymi praktykami w życiu dorosłym (Tammelin, Näyhä, Hills, Järvelin, 2003). carried out among students of sports classes. They indicate that people attending them are characterized by greater discipline, a higher assessment of behavior, a sense of common interest, and their results in education are better or equivalent to peers' results (Nowocień, 2001). Sports training according to the Polish luminaries of the theory of sport, M. Demel and A. Composition, requires from the person "a sense of responsibility, consistency, self-discipline, submission to the rules of the game and arbitration, and any violations of the rules take revenge by themselves or are sanctioned by judges" (Sas-Nowosielski, 2002, p. 60). The oftenemphasized advantage of sports activity in the process of socialization of the young generation is shaping the ability to cooperate in a group, which is a valued element of participation in social life, an indicator of the degree of socialization. First, it takes place during games and team activities which have many valuable features. This fact has been noticed since the time when games also entered education as one of the methods of natural child training (Zdebska, 2012). Among the features that are acquired by children and young people through team sports, M. Tomecka lists: shaping the ability to share experience with others and feeling solidarity with them; getting rid of selfishness, giving up individual benefits for the general good (Tomecka, 2012). For young people, a team of peers becomes an important, if not the most important group to which they belong, in which interpersonal bonds of a special nature are established.

\section{Individual hygiene and sport and socialization of children and youth}

Participation in sport includes a hygienic pattern of physical culture being also implemented. The aim of it is to take care of health and fight disease, in accordance with the maxim of the Roman poet Juewenalis: "A healthy mind in a healthy body". In the process of socialization, young people acquire a proper attitude to health as a valuable value not only from an individual point of view, but also according to the general public opinion. Young athletes, under the supervision of teachers and trainers, are encouraged to follow a healthy lifestyle: nutrition, hydration, personal hygiene (Khaled Ahmad Ibrahim, Brée, Naja, 2017). Many of them end their participation in sports competitions when they enter adulthood, but the previously developed patterns of behavior are often retained. Research shows some significant relationship between being physically active in childhood and similar practices in adulthood (Tammelin, Näyhä, Hills, and Järvelin, 2003). 


\section{Sport a postawy patriotyczne dzieci i młodzieży}

Nie tylko samo czynne uczestnictwo w sporcie, ale również odbiór treści z nim związanych może mieć pozytywny wpływ na wprowadzanie młodego pokolenia do życia w społeczeństwie. Sport to często lekcja obywatelskości; to na jego gruncie młodzi adepci mogą doświadczyć jednej z ważniejszych wartości demokratycznego społeczeństwa, jaką jest równość i podmiotowość wszystkich osób. Pisze o tym Stanisław Kowalczyk: „Sport jest fenomenem ponadklasowym i ponadnarodowym, niezależnym od wieku, kręgu kultury i przynależności rasowej. Jedynym warunkiem uczestnictwa w grze sportowej jest uznanie obowiązujących w konkretnej dyscyplinie reguł działania" (Nowocień, 2013, s. 196). Telewizyjne transmisje wydarzeń sportowych, zwłaszcza tych rangi mistrzowskiej, w której uczestniczą reprezentanci danego kraju, są doskonała szkoła patriotyzmu: „Obecność w ceremoniale symboliki narodowej (flaga, godło, hymn) sprzyja budowaniu świadomości, tożsamości narodowej. Sportowiec reprezentant kraju jest, bowiem przedstawicielem $<<$ nas $>>$ jako społeczeństwa, jako narodu. Tym samym, więc, sport może stanowić jedną z najlepszych lekcji patriotyzmu" (Zdebska, 2012, s. 138).

Wspominając o roli mediów nie można pominąć dużego znaczenia „gwiazd sportu”, które swój status społeczny osiągnęły dzięki ciężkiej pracy, wytrwałości, solidności i posiadanym talentom. Warto przypomnieć, że w procesie socjalizacji wiodące znaczenie mają wzorce dostarczane przez osoby, z którymi młody człowieka ma bezpośredni lub pośredni kontakt. Sławni sportowcy często przez media są wykorzystywani do propagowania właściwych wzorców zachowania. Zwłaszcza, gdy gwiazda sportu zaczyna być „znaczącym innym”, kiedy staje się dla młodego człowieka idolem, namiastką autorytetu. Tego ostatniego dzieci i młodzież w okresie adolescencji potrzebują w sposób szczególny; o ile w czasie socjalizacji pierwotnej są nim głównie rodzice, to na kolejnym etapie pojawiają się inne osoby, a wśród nich nierzadko jest nauczyciel wychowania fizycznego lub trener. Osoby te nie tylko odpowiadają za przygotowanie ucznia czy zawodnika do rywalizacji sportowej, ale też poprzez swoje postepowanie oraz sprawowanie kontroli nad zachowaniem uczniów wskazują im, jak rozładowywać nagromadzoną życiową energię, rozwiązywać konflikty czy dokonywać właściwych wyborów. Uczą etycznego postępowania, które jest ważne nie tylko na boisku, ale w całym życiu człowieka (Saska-Dymicka, 2011). W tym kontekście ważne jest jaki system wartości tworzą przewodnicy dzieci i młodzieży po świecie sportu, czy potrafią rozpoznawać i zaspokajać potrzeby młodych ludzi w klimacie szacunku, współpracy i zaufania (Czechowski, Dąbrowska, 2011). Często też sposób trenowania może mieć większy wpływ na socjalizacje i wychowanie do wartości i zdrowego stylu życia, niż same uczestnictwo w sporcie (Khaled Ahmad Ibrahim, Brée, Naja, 2017; Manchev, 2017).

\section{Sport and patriotic attitudes of children and youth}

Not only active participation in sport, but also the reception of content related to it, can have a positive impact on introducing the young generation to life in society. Sport is often a lesson in citizenship; it is on its basis that young adepts can experience the most important values of a democratic society, equality and subjectivity of all people. Stanisław Kowalczyk writes about it: "Sport is a supra-class and supranational phenomenon, independent of age, culture and race affiliation. The only condition for participation in a sports game is to recognize the rules of operation applicable in a specific discipline" (Nowocień, 2013, p. 196). Television broadcasts of sports events, especially those of the championship rank, in which representatives of a given country participate, are an excellent school of patriotism: "The presence of national symbols (flag, emblem, anthem) in ceremonials helps build national awareness and identity. The athlete representing the country is the representative of $<<$ us $>>$, as a society, as a nation. Thus, sport can be one of the best lessons of patriotism" (Zdebska, 2012, p. 138).

When mentioning the role of the media, one cannot ignore the great importance of "sports stars" who achieved their social status thanks to hard work, perseverance, reliability and their talents. It is worth recalling that in the process of socialization the models provided by people with whom a young person has direct or indirect contact are of major importance. Famous athletes are often used by the media to promote proper behavior patterns. Especially when a sports star begins to be a "significant other", when they become an idol for a young person, a substitute for authority. Children and young people in adolescence need the latter in a special way; while in primary socialization it is mainly parents, then other people appear at the next stage, and often there is a physical education teacher or trainer among them. The people are responsible not only for preparing the student or competitor for sports competition, but also through their behavior and controlling the behavior of students, they show them how to discharge the accumulated life energy, resolve conflicts or make the right choices. They teach ethical behavior, which is important not only on a pitch, but throughout a person's life (SaskaDymicka, 2011). In this context, it is important what value system guides children and young people create around the world of sport, whether they can recognize and satisfy the needs of young people in an atmosphere of respect, cooperation and trust (Czechowski, Dąbrowska, 2011). Often the way of training can have a greater impact on socialization and education for values and a healthy lifestyle than participation in sport itself (Khaled Ahmad Ibrahim, Brée, Naja, 2017; Manchev, 2017). 


\section{Zakończenie}

W świetle przeprowadzonej analizy literatury przedmiotu badania nad rolą sportu w socjalizacji dzieci i młodzieży są prowadzone od połowy XX w., natomiast jeszcze wcześniej podjęto rozważania nad rolą zabawy w rozwoju dziecka. Uczestnictwo w różnych formach aktywności sportowej skutkuje nie tylko zmianami w obrębie zdrowia fizycznego i sprawności motorycznej młodego człowieka, ale też przynosi szereg korzyści w kształtowaniu jego osobowości oraz uspołecznieniu. Sport jest taką dziedziną aktywności, w której młody człowiek dzięki kontaktami z rówieśnikami oraz osobami dorosłymi rozwija się społecznie i moralnie. Jak słusznie zauważa J. Derbich „poprzez uprawianie sportu można nie tylko nauczyć się wygrywać czy przegrywać, ale można się nauczyć żyć - godnie i z szacunkiem, którym obdarza się siebie, drugiego człowieka, oraz otaczającą nas wszystkich zmaterializowaną i symboliczną rzeczywistość" (Derbich, 1993, s. 145). Kształtowany jest właściwy stosunek do własnej osoby, innych ludzi, czy też takich wartości i wspólnot społecznych, jak zdrowie, praca, środowisko rówieśnicze, rodzina. Praktycznych umiejętności potrzebnych ludziom w życiu można uczyć się $\mathrm{w}$ połączeniu $\mathrm{z}$ umiejętnościami sportowymi, które kształtują w młodym człowieku gotowość do pokonywania wyzwań związanych codzienną egzystencją. Nabyte w trakcie uczestnictwa w aktywności sportowej zachowania mogą, bowiem być skutecznie przenoszone na inne dziedziny życia.

\section{Summary}

In the light of the literature analysis on the subject, research on the role of sport in the socialization of children and adolescents has been conducted since the mid-twentieth century, while the role of play in child development was considered even earlier. Participation in various forms of sports activities results not only in changes in the physical health and motor fitness of a young person, but also brings a number of benefits in shaping his personality and socialization. Sport is an area of activity in which a young person develops socially and morally thanks to contacts with peers and adults. As J. Derbich rightly observes, "by practicing sport, you can learn more than how to win or lose, but you can also learn to live with dignity and respect for yourself, another person, and the materialized and symbolic reality that surrounds us all" (Derbich, 1993 , p. 145). The right attitude towards oneself, other people, or such values and social communities as health, work, peer environment, family is formed. Practical skills that people need in life can be learned together with sports skills that shape the young person's readiness to overcome the challenges of everyday existence. Behaviors acquired during participation in sports activities can be effectively transferred to other areas of life.

\section{Literatura/ References:}

1. Berger, P. L., Luckmann, T. (2010). Społeczne tworzenie rzeczywistości. Warszawa: Państwowe Wydawnictwo Naukowe.

2. Cynarski, W. (2012). Antropologia sztuk walki - spojrzenie filozoficzne, Rozprawy Naukowe Akademii Wychowania Fizycznego we Wrocławiu, 36, s. 90-103.

3. Cynarski, W., Lee-Barron, J. (2014). Philosophies of martial arts and their pedagogical consequences, IDO MOVEMENT FOR CULTURE. Journal of Martial Arts Anthropology 14(1), pp. 11-19.

4. Czechowski, M., Dąbrowska, A. (2011). Fair play w sporcie i życiu młodzieży, Warsztaty dydaktyczne dla nauczycieli i młodzieży szkolnej, z. 1. Warszawa: Klub Fair Play PKOI.

5. Demel, M., Skład, A. (1986). Teoria wychowania fizycznego dla pedagogów. Warszawa: Państwowe Wydawnictwo Naukowe.

6. Derbich, J. (1993). Przygotowanie do wartości poprzez uprawianie sportu. W: Z. Dziubiński (red), Wychowawcze aspekty sportu, (s. 143-149). Warszawa: Salezjańska Organizacja Sportowa.

7. Filipiak, M. (2000). Socjologia kultury. Lublin: Wydawnictwo UMCS.

8. Holt N. L., Tink L. N., Mandigo J. L., Fox K. R. (2008). Do Youth Learn Life Skills through Their Involvement in High School Sport? A Case Study. Canadian Journal of Education / Revue canadienne de l'éducation, 31(2), pp. 281-304. DOI: 10.2307/20466702, https://www.jstor.org/stable/20466702?seq=1

9. Khaled, Ahmad Ibrahim G., Brée J., Naja M. (2017). The Influence of Sport Practice in Federal French Sport Clubs on the Sensitivityof Children to Values and Healthy Lifestyle: A Qualitative Exploratory Study. In: Rossi P. (eds), Marketing at the Confluence between Entertainment and Analytics. Developments in Marketing Science: Proceedings of the Academy of Marketing Science. (pp. 1365-1369). Springer, Cham. https://doi.org/10.1007/978-3-319-47331-4_267

10. Kosiewicz, J. (2010). Sport poza dobrem i złem moralnym. Studia Humanistyczne, 10, s. 27-41.

11. Kowalczyk, S. (2002). Elementy filozofii i teologii sportu. Lublin: Towarzystwo Naukowe KUL.

12. Kowalczyk, S. (2003). Społeczno-integracyjna funkcja sportu. W: Z. Dziubiński (red.), Społeczny wymiar sportu (s. 25-30). Warszawa: Salezjańska Organizacja Sportowa RP. 
13. Kulczyńska, U. (2019). Sport jako obszar konstruowania tożsamości mężczyzn. W: M. Dąbrowska, A. Radomski (red.), Męskość jako kategoria kulturowa. Praktyki męskości (s. 86-99). Lublin: Wydawnictwo PWiE.

14. Kunicki, B., J. (2011). Społeczeństwo, kultura, kultura fizyczna. W: Z. Dziubiński, Z. Krawczyk (red), Socjologia kultury fizycznej (s. 59-66). Warszawa: AWF.

15. Lipiec, J. (2012). Socjalizacyjna lekcja sportu. W: Z. Dziubiński, K. W. Jankowski (red), Kultura fizyczna a socjalizacja, (s. 15-23). Warszawa: AWF, Salezjańska Organizacja Sportowa.

16. Lipoński, W. (2014). Brytyjska geneza sportu i fair play. W: K. Hądzelek (red.) Czysta gra. Fair Play, (s. 122139). Warszawa: Polski Komitet Olimpijski.

17. Manchev, S. (2017). Children and Socialization: Crossing Social and Cultural Boundaries, The New Diversity of Family Life in Europe, In: Çitlak B., Kurtenbach S., Lueneburg M., Zlatkova M. (eds), The New Diversity of Family Life in Europe (pp. 163-179). Springer VS, Wiesbaden. https://doi.org/10.1007/978-3658-17857-4_11

18. Mortimer, J. T., Simmons, R. G. (1978). Adult sozialization. Annual Review of Sociology, 4, pp. 421-454. https://www.jstor.org/stable/2945977

19. Nosal, P. (2015). Społeczne ujęcie sportu. (Trudne) definiowanie zjawiska czy dyskurs? Przegląd Socjologii Jakościowej, 11(2), s. 16-38.

20. Nowocień, J. (2014). Olimpizm i fair play jako źródło wartości w nowoczesnym procesie edukacji. W: K. Hądzelek (red.), Czysta gra. Fair Play, (s. 198-204). Warszawa: Polski Komitet Olimpijski.

21. Nowocień, J. (2001). Sport i olimpizm w systemie wychowawczym współczesnej szkoły. Warszawa: AWF

22. Nowocień, J. (2013). Sport w kulturze i wychowaniu obywatelskim. W: J. Nowocień, K. Zuchora (red.), Sport w kulturze zdrowia, czasu wolnego i edukacji olimpijskiej w 150-lecie urodzin Pierre'a de Coubertin, (s. 183 - 199). Warszawa: AWF.

23. Ommundsen, Y., Løndal, K., Loland, S. (2014). Sport, Children, and Well-Being. In: A. Ben-Arieh, F. Casas, I Frønes, J. E. Korbin (eds, Handbook of Child Well-Being (p. 911-940). Springer Netherlands. https://doi. org/10.1007/978-90-481-9063-8_148

24. Organista N. (2012). Nierówności płciowe w procesie socjalizacji do kultury fizycznej. W: Z. Dziubiński, K. W. Jankowski (red). Kultura fizyczna a socjalizacja (s. 193 - 202). Warszawa: AWF, Polska Akademia Olimpijska, Fundacja „Centrum Edukacji Olimpijskiej.

25. Pieter, J. (1976). Historia psychologii. Warszawa: PWN.

26. Pietrzak, H., Cynarski, W. (2000). Psychologia duchowej drogi sztuk walki, IDO - RUCH DLA KULTURY, t. I, s. 202-210.

27. Schaffer, R. H. (2006). Rozwój społeczny dzieciństwo i młodość. Kraków: Wydawnictwo Uniwersytetu Jagiellońskiego.

28. Sage, G. H. (1979). Sport and the Social Sciences. The Annals of the American Academy of Political and Social Science, Vol. 445 (1), pp. 1-14. https://doi.org/10.1177/000271627944500103

29. Sas-Nowosielski, K. (2002). O możliwościach wykorzystania kultury fizycznej w resocjalizacji nieletnich. Warszawa: Wydawnictwo WSP TWP.

30. Saska-Dymicka, J. (2011). Sport młodzieżowy kuźnią charakteru i postaw społecznych, Zeszyty Naukowe Uniwersytetu Szczecińskiego. Ekonomiczne Problemy Usług, (78), s. 113-125.

31. Stryczek, M. (2011). Aksjologia sportu. Lublin: Katolicki Uniwersytet Lubelski Jana Pawła II.

32. Szczepański, J. (1970). Elementarne pojęcia socjologii. Warszawa: Państwowe Wydawnictwo Naukowe.

33. Szymański, M. J. (2013). Socjologia edukacji. Zarys problematyki. Kraków: Impuls.

34. Tammelin T., Näyhä S., Hills A. P., Järvelin M-R. (2003). Adolescent participation insports and adult physical activity, American Journal of Preventive Medicine, 24(1), pp. 22-28. https://doi.org/10.1016/S07493797(02)00575-5

35. Tillmann, K. J. (2013). Teorie socjalizacji. Społeczność, instytucja, upodmiotowienie. Warszawa: Państwowe Wydawnictwo Naukowe.

36. Tomecka, M. (2012). Socjalizacja a gry zespołowe. W: Z. Dziubiński, K. W. Jankowski (red.), Kultura fizyczna a socjalizacja (s. 175-184). Warszawa: AWF.

37. Wołoszyn, S. (1964). Dzieje wychowanie i myśli pedagogicznej w zarysie, Warszawa: Państwowe Wydawnictwo Naukowe.

38. Zdebska, H. (2010). Fair play a etyka współpracy, W: Z. Żukowska, R. Żukowski (red.) Fair play w sporcie i olimpizmie. Szansa czy utopia (s. 52-59). Warszawa: Polski Komitet Olimpijski, Klub Fair Play.

39. Zdebska, H. (2012). Socjalizacja i sport. W: Z. Dziubiński, K. W. Jankowski (red.), Kultura fizyczna a socjalizacja (s. 131-149). Warszawa: AWF.

40. Ziółkowski, A. (2004). Rola sportu w rozwoju społeczno-moralnym młodych zawodników. W: M. Krawczyński, D. Nowicki (red.), Psychologia sportu w treningu dzieci i młodzieży (s. 11-35). Warszawa: Centralny Ośrodek Sportu.

41. Żukowska, Z., Żukowski R (2010). Fair play jako wartość edukacyjna w sporcie a sprawności moralne nauczyciela wychowania fizycznego i trenera. W: Z. Żukowska, R. Żukowski (red.), Fair play w sporcie i olimpizmie. Szansa czy utopia (s. 60-71). Warszawa: Polski Komitet Olimpijski, Klub Fair Play. 